\title{
Isoenzymatic polymorphism in Citrus spp. and Poncirus trifoliata (L.) Raf. (Rutaceae)
}

\author{
Valdenice Moreira Novelli $^{1,2}$, Marcos Antonio Machado ${ }^{3}$ and Catalina Romero Lopes ${ }^{2}$
}

\begin{abstract}
Isoenzymatic polymorphism analysis was used to determine genetic variability among species and hybrids of Citrus spp. and one accession of Poncirus trifoliata (L.) Raf. Ten enzymatic systems aspartate aminotransferase (AAT), acid phosphatase (ACP), leucine aminopeptidase (LAP), 6-phosphogluconate dehydrogenase (6-PGD), isocitrate dehydrogenase (IDH), phosphoglucoisomerase (PGI), phosphoglucomutase (PGM), diaphorase (DIA), shikimate dehydrogenase (SKD) and peroxidase (PRX) were analyzed. Twenty loci and 48 alleles were identified. Sweet orange cultivars $(C$. sinensis $(\mathrm{L})$. Osbeck) showed the highest polymorphism with the largest number of heterozygous loci, although the alleles of those loci were the same in all cultivars, with the exception of Westin and Lima graúda. Mandarins (C. reticulata Blanco) exhibited diverse patterns, whereas Poncirus trifoliata (L.) Raf. showed high variability with all Citrus species and hybrids. Exclusive phenotypes were observed in some enzymatic systems, and similar patterns were found among interspecific hybrids and their putative parents.
\end{abstract}

\section{INTRODUCTION}

The genus Citrus belongs to the subtribe Citrinae, tribe Citreae, subfamily Aurantioideae of the family Rutaceae (Swingle and Reece, 1967). Taxonomic relationships among members of this genus were established by Swingle and Reece (1967) and Tanaka (1954). However, these classifications differ considerably in the number of species, since Swingle and Reece recognized 16 species and Tanaka 163 species.

The Citrus genus includes the most widely producing fruit species in the world and is highly polymorphic. Several species are used as scion cultivars, such as sweet orange, mandarins, lemons and grapefruit. Many species and hybrids with related genera can also be used as rootstocks. Poncirus trifoliata (L.) Raf. has importance as a rootstock for several cultivars around the world. However, Citrus breeding programs have been hampered by factors associated with reproductive biology (sterility, incompatibility, nucellar embryony, juvenility) and scant information on the nature and mode of inheritance of economically important traits (Torres et al., 1978; Jarrel et al., 1992).

Researchers have recognized the need for genetical studies as well as identification of genetic markers as tools for clarifying taxonomic relationships and improving breeding programs in the genus (Esen and Scora, 1977; Torres et al., 1978; Gogorcena and Ortiz, 1993). Furthermore, correct identification is important for certification and registration of new cultivars. The genetic variability of Citrus and associated genera has been evaluated by morphological descriptors, which have low discriminating capacity, as well as biochemical and molecular markers (Esen and Scora, 1977; Handa et al., 1986). Isoenzymes have been extensively used as genetic markers in Citrus spp. due to their low cost and feasibility as codominant markers (Torres et al., 1978; Gogorcena et al., 1990; Durham et al., 1992; Herrero et al., 1996).

We studied the genetic variability of isoenzymes in different species of Citrus, their hybrids and Poncirus trifoliata (L.) Raf., to provide basic information for breeding programs.

\section{MATERIAL AND METHODS}

All accessions analyzed (Table I) belong to the Citrus Germplasm Collection at the Centro de Citricultura "Sylvio Moreira”, IAC, Cordeirópolis, SP, Brazil. Young leaves from fully expanded and mature plants of similar age were collected and maintained at low temperature in polyethylene bags. In the laboratory, the leaves were washed in distilled water and chopped into pieces. Leaf tissue $(0.30 \mathrm{~g})$ from each sample was ground with $0.5 \mathrm{ml}$ of $0.05 \mathrm{M}$ Tris- $\mathrm{HCl}$ buffer, $\mathrm{pH} 7.5$, containing $0.8 \mathrm{mM}$ DL-dithiothreitol (DLDTT), $1.5 \mathrm{mM}$ sodium metabisulfite, $1 \%$ polyethylene glycol (molecular mass, 6000), $10 \%$ sucrose and $0.2 \%$ Triton X-100 (Bechara, 1996, with modifications). The supernatants were stored at $-20^{\circ} \mathrm{C}$. The samples were assayed for the following enzymatic systems: phosphoglucoisomerase

${ }^{1}$ Departamento de Ciências Biológicas, Universidade Estadual de Feira de Santana, km 03 BR 116, Campus Universitário, 44031-460 Feira de Santana, BA, Brasil. Send correspondence to V.M.N. Fax: +55-75-224-8019.

${ }^{2}$ Departamento de Genética, Instituto de Biociências, Universidade Estadual Paulista “Júlio de Mesquita Filho”, Botucatu, SP, Brasil. ${ }^{3}$ Centro de Citricultura Sylvio Moreira, Instituto Agronômico de Campinas, Cordeirópolis, SP, Brasil. 
(PGI), phosphoglucomutase (PGM), leucine aminopeptidase (LAP), isocitric acid dehydrogenase (IDH), catodic and anodic peroxidase (PRX), 6-phosphogluconate dehydrogenase (6-PGD), shikimate dehydrogenase (SKD), aspartate aminotransferase (AAT), diaforase (DIA) and acid phosphatase (ACP). Electrophoresis was performed in horizontal starch gels according to Conkle et al. (1982), Cheliak and Pitel (1984) and Ballvé et al. (1995). The gels were stained for specific systems (Conkle et al., 1982; Tanksley and Orton, 1983; Cheliak and Pitel, 1984; Soltis and Soltis, 1989). The stained gels were rinsed in distilled water and fixed using acetic acid:glycerol:water (1:1:8). Specific genotypes were inferred from the banding patterns. Gene loci and alleles were named and interpreted according to Torres et al. $(1978,1982)$.

A similarity matrix was generated using the Nei unbiased genetic identity (GI) coefficient (1978, in Swofford and Selander, 1989) with the software BIOSYS 1.7 based on allelic frequencies (Swofford and Selander, 1989), and a cluster analysis using the unweighted pair-group method using arithmetic averages (UPGMA) was performed from the similarity matrix (Rohlf, 1992).

\section{RESULTS}

The number of loci and alleles in each accession varied according to the isoenzymatic system tested. Twenty loci and 48 alleles were detected from the 10 enzymatic systems analyzed (Table II). The degree of polymorphism detected (from most to least) was PRX, PGM, SKD, DIA, IDH, 6-PGD, AAT, ACP, PGI and LAP. Several accessions presented exclusive phenotypes in different enzymatic systems, and similar patterns were found among hybrids and their putative parents (Table II).

Table I - Citrus species, cultivars and hybrids analyzed (identified according to Tanaka, 1954).

\begin{tabular}{|c|c|c|}
\hline Species & Cultivars & Acessions \\
\hline \multicolumn{3}{|l|}{ Rootstock cultivars } \\
\hline Sour orange (Citrus aurantium L.) & Sour orange Tunis & CV 237 \\
\hline Rangpur lime (Citrus limonia Osbeck) & Rangpur lime Limeira & Limeira \\
\hline Cleopatra mandarin (Citrus reshni Hort. ex. Tan.) & Cleopatra mandarin & Mother plant \\
\hline Sunki mandarin (Citrus sunki Hort. ex. Tan.) & Sunki mandarin & Mother plant \\
\hline Trifoliata orange (Poncirus trifoliata (L.) Raf. Sylva Tellur) & Trifoliata orange & Mother plant \\
\hline \multicolumn{3}{|l|}{ Scion cultivars } \\
\hline \multirow[t]{8}{*}{ Sweet orange (Citrus sinensis (L.) Osbeck) } & Hamlin & Multiplication block \\
\hline & Lima graúda EEL & CV 1587 \\
\hline & Mortera & CN131 \\
\hline & Natal & Multiplication block \\
\hline & Pera & Multiplication block \\
\hline & Valência & Multiplication block \\
\hline & Valência folha murcha & Multiplication block \\
\hline & Westin & Multiplication block \\
\hline \multirow[t]{11}{*}{ Mandarins (Citrus reticulata Blanco) } & Carvalhaes Portugal & CN546 \\
\hline & Clementina & CV 174 \\
\hline & Cravo & Multiplication block \\
\hline & Dancy & $\mathrm{CN} 206$ \\
\hline & FremontEUA & CN543 \\
\hline & Hansen Austrália & CN596 \\
\hline & Kara & CN207 \\
\hline & Mel & $\mathrm{CN} 205$ \\
\hline & Paraguaia EEP - RS & CN492 \\
\hline & Poncan & Multiplication block \\
\hline & Vermelha 17 -RS & CN511 \\
\hline Mandarin Citrus nobilis Loureiro & King & CV 179 \\
\hline Mandarin Citrus unshiu Marcovitch & Satsuma Japão & CN527 \\
\hline \multicolumn{3}{|l|}{ Hybrids } \\
\hline C. paradisi- 'Duncan' x C. reticulata 'Dancy' & Orlando Tangelo & Mother plant \\
\hline $\begin{array}{l}\text { C. reticulata 'Clementina' } \mathrm{x} \text { Tangelo Orlando } \\
\text { (C. paradisi -'Duncan' x C. reticulata 'Dancy') }\end{array}$ & Lee IPEACS - RJ & CV 441 \\
\hline C. sinensis x C. reticulata & Murcott Tangor & Mother plant \\
\hline $\begin{array}{l}\text { C. reticulata 'Clementina' x Tangelo Orlando } \\
\text { (C. paradisi- 'Duncan' x C. reticulata 'Dancy') }\end{array}$ & Nova EEL Tangelo & CV 1583 \\
\hline $\begin{array}{l}\text { C. reticulata 'Clementina' x Tangelo Orlando } \\
\text { (C. paradisi- 'Duncan' x C. reticulata 'Dancy') }\end{array}$ & Osceola IPEACS - RJ & CV 443 \\
\hline
\end{tabular}




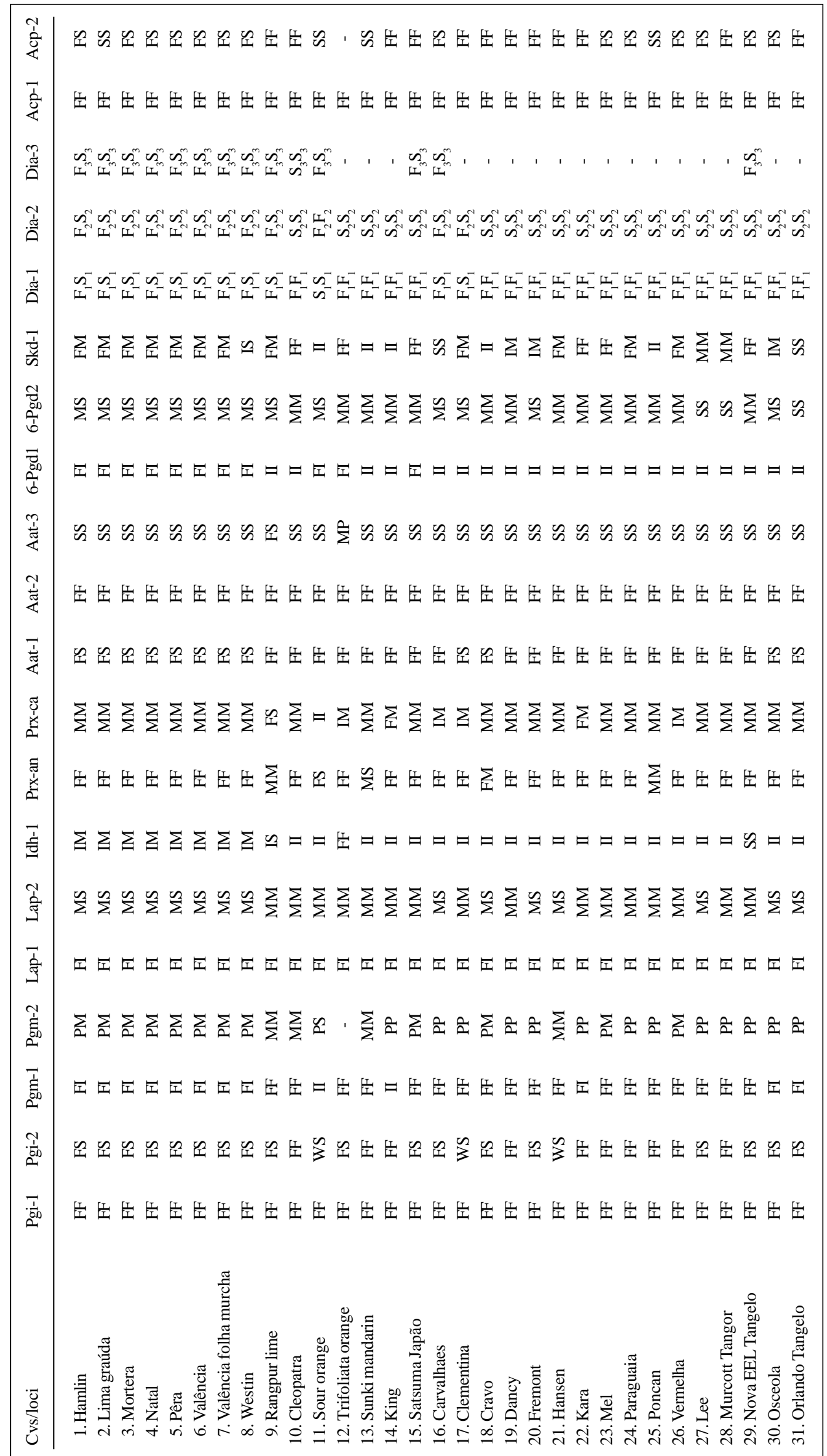


The GI obtained from the allelic frequencies (Nei, 1978 in Swofford and Selander, 1989) and the UPGMA cluster analysis ranged from 1 , the most related accessions, to 0.65 for the less related (Figure 1). The highest GI was observed among the different cultivars of $C$. sinensis (0.94 to 1.0). This group was very distinct from the other accessions.

The $C$. reticulata accessions did not cluster into one group. Some were more similar to accessions of other species. Carvalhaes, Clementina and Fremont accessions (C. reticulata) were grouped together with Osceola, Lee, Murcote and Orlando hybrids, that have $C$. reticulata as one of the progenitors. Another subgroup included some $C$. reticulata accessions and $C$. reshni, $C$. nobilis species and Nova tangelo.

\section{DISCUSSION}

According to Iglesias et al. (1974), isoenzymatic variability in Citrus is expected since many species and cultivars probably originated through natural hybridization, which is the route to heterozygosity in plants.

Sweet orange cultivars (C. sinensis) showed the highest level of polymorphism, with 13 or 14 heterozygous loci out of 20 (Table II), although the alleles at these loci were almost always the same. Researchers suggest that this species originated from hybridization between $C$. grandis (L.) Osbeck and C. reticulata Blanco (Scora, 1975, 1988; Esen and Scora, 1977). Although heterozygosity within these cultivars is high, the need for uniform cultivation must have resulted in the selection of a few variants, that had the de-

\begin{tabular}{lllllll}
0.60 & 0.67 & 0.73 & 0.80 & 0.87 & 0.93 & 1.00 \\
\hline
\end{tabular}

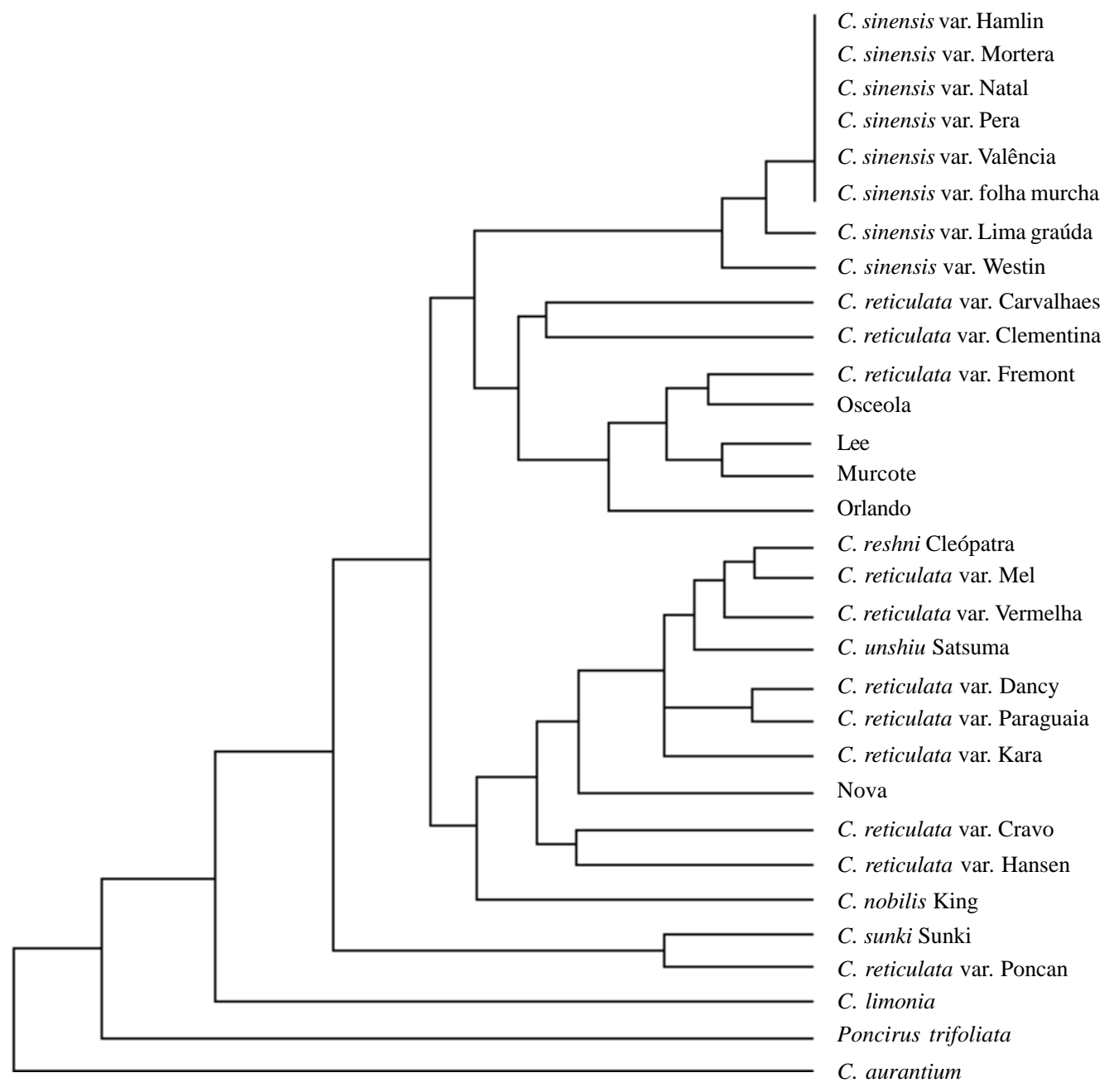

Figure 1 - UPGMA cluster (Nei, 1978, in Swofford and Selander, 1989) identity genetic coefficient matrix of isoenzymatic polymorphism for different species of Citrus, their hybrids and Poncirus trifoliata (L.) Raf. 
sirable genotypic constitution, and these were multiplied through vegetative propagation (Barret and Rhodes, 1976).

However, cultivars Westin and Lima graúda showed specific isoenzymatic patterns for SKD (IS) and ACP (FF/ SS), respectively, suggesting that less hybridization has occurred among these cultivars. These enzyme systems could be useful for identification. This could be important, since few studies have focused on polymorphism within cultivars of $C$. sinensis (Esen and Scora, 1977; Vardi, 1988; Sawasaki et al., 1992; Herrero et al., 1996). However, several cultivars of sweet orange originated from somatic mutations of seedlings or limbsport and such mutations have been difficult to detect by codominant markers, like isoenzymes.

In general, mandarins were found to be less polymorphic than sweet orange cultivars. Fourteen different heterozygous loci were observed, and the number of heterozygous loci per individual plant ranged from one to nine (Table II). The lower degree of polymorphism in this group may be due to the fact that this species originated from a cross either between two unknown $C$. reticulata cultivars or one $C$. reticulata cultivar and a different species. In all accessions, six homozygous loci and one heterozygous locus presented the same phenotype. Therefore, $C$. reticulata cultivars showed less polymorphism within groups than among them, suggesting some intraspecific variability from a narrow genetic base.

Esen and Scora (1977) observed complete homology in amylase in Clementina and Dancy ( $C$. reticulata), Cleópatra (C. reshni), and King (C. nobilis). In the present study seven enzymatic systems (PGI, PGM, PRX, AAT, 6PGD, SKD and DIA) were useful in detecting differences between some of the accessions analyzed from the cultivars cited above. In fact, some phenotypes were specific, such as King (PGM = II/PP), Cleópatra and Clementina mandarins $\left(\mathrm{DIA}=\mathrm{F}_{1} \mathrm{~F}_{1} / \mathrm{S}_{2} \mathrm{~S}_{2} / \mathrm{S}_{3} \mathrm{~S}_{3}\right.$, and $\mathrm{F}_{1} \mathrm{~S}_{1} / \mathrm{F}_{2} \mathrm{~S}_{2}$, respectively) (Table II).

According to Scora (1975) and Barret and Rhodes (1976), the sour orange, C. aurantium, probably originated from a cross between $C$. grandis (L.) Osbeck (pummelo) and $C$. reticulata Blanco (mandarin). In this work some alleles were common to $C$. aurantium and one of its probable progenitors, $C$. reticulata. In sour orange, specific phenotypes were detected in three enzymatic systems (PGM (II/PS), PRX (FS/II), DIA ( $\left.\mathrm{S}_{1} \mathrm{~S}_{1} / \mathrm{F}_{2} \mathrm{~F}_{2} / \mathrm{F}_{3} \mathrm{~S}_{3}\right)$ ), making these three systems useful in cultivar identification. Similarly, $C$. limonia Osbeck showed specific phenotypes in three enzymatic systems: PRX (MM/FS), AAT (FF/FF/FS) and IDH (IS); $C$. sunki (Sunki) and C. reticulata cvs Cravo and Poncan could be identified by the following PRX specific patterns, MS/MM, FM/MM and MM/MM, respectively.

Some enzymatic phenotypes were specific to hybrids, such as Nova tangelo, which showed the IDH specific phenotype SS. The hybrids Lee, Murcote and Orlando shared the same phenotype II/SS of 6-PGD, while Lee and Murcote had the phenotype MM of SKD. As expected, several alleles occurred in some hybrids as well as their probable progenitors.
The accession of Poncirus trifoliata showed specific phenotypes for four enzymatic systems: PGM (FF/--), IDH (FF), AAT (FF/FF/MP) and ACP (FF/--). In general, the phenotypes were very similar to those described by Torres et al. (1978, 1982), Ballvé et al. (1991), Sawazaki et al. (1992) and Jarrel et al. (1992). Some alleles shared by $P$. trifoliata and other Citrus species suggest that the two genera, Citrus and Poncirus, are structurally and functionally related at the genomic level, although taxonomically distinct on a morphological level, which would explain the results of crossing these species (Torres et al., 1985; Jarrel et al., 1992).

According to Scora (1975), Esen and Scora (1977), Handa et al. (1986), Scora (1988), Vardi (1988) and Roose (1988), C. reticulata, a possible progenitor of several species, is related to many of the accessions. Thus, the similarity of $C$. reticulata to the other species is understandable, considering the polyphyletic origin of Citrus cultivated species.

Our data show that $C$. limonia, Poncirus trifoliata and C. aurantium are related species, but with a minor degree of intragroup similarity and $C$. aurantium is the most differentiated among them (Figure 1). It has been suggested that $C$. reticulata is involved in the origin of $C$. aurantium and C. limonia (Hodgson, 1967). The similarity observed here between the genera Poncirus and Citrus had been confirmed at the molecular level by Torres et al. (1985) and Jarrel et al. (1992), who detected high structural and functional homology between the genomes of the two genera.

In conclusion, the isoenzyme phenotype results showed a high level of heterozygosity and allows one to infer the genotype of the 31 accessions studied and the genetic similarity among them.

\section{ACKNOWLEDGMENTS}

Thanks are due to Dr. Cláudio Costa and Dr. Marcos Gimenes for their assistance. V.M.N. and C.R.L. are recipients of CNPq fellowship. Publication supported by FAPESP.

\section{RESUMO}

A análise do polimorfismo isoenzimático foi usada para determinar a variabilidade genética entre espécies e híbridos de Citrus spp. e um acesso da espécie Poncirus trifoliata (L.) Raf. Dez diferentes sistemas enzimáticos foram analisados, incluindo aspartato aminotransferase (AAT), fosfatase ácida (ACP), leucina aminopeptidase (LAP), 6-fosfogluconato desidrogenase (6-PGD), isocitrato desidrogenase (IDH), fosfoglucose isomerase (PGI), fosfoglucomutase (PGM), diaforase (DIA), shiquimato desidrogenase (SKD) e peroxidase (PRX). Um total de 20 locos e 48 alelos foram identificados. Os cultivares de laranja doce (C. sinensis (L.) Osbeck) apresentaram um grande número de locos heterozigotos, mas similares entre eles, com exceção dos cultivares Westin e Lima graúda. Os cultivares de mandarim (C. reticulata Blanco) apresentaram diferentes padrões entre eles, enquanto que Poncirus trifoliata (L.) Raf. apresentou elevada diferenciação em relação a 
todas as espécies de Citrus e híbridos. Fenótipos exclusivos foram observados em alguns sistemas enzimáticos, sendo encontrados padrões similares entre os híbridos interespecíficos e seus possíveis parentais.

\section{REFERENCES}

Ballvé, R.M.L., Bordignon, R., Medina Filho, H.P., Siqueira, W.J., Sobrinho, J.T. and Pompeu Jr., J. (1991). Isoenzimas na identificação precoce de híbridos e clones nucelares no melhoramento de citros. Bragantia 50: 57-76.

Ballvé, R.M.L., Medina Filho, H.P., Bordignon, R. and Lima, M.M.A. (1995). Methodology for starch gel electrophoresis and protocols for isozymes of 32 plant genera. Rev. Bras. Genet. 18: 491-502.

Barret, H.C. and Rhodes, A.M. (1976). A numerical taxonomic study of affinity relationships in cultivated Citrus and its close relatives. Syst. Bot. 1: 105-136.

Bechara, M.D. (1996). Estudo da variabilidade isoenzimática em acessos de Arachis pintoi Krapovickas and Gregory provenientes da Bacia do Rio Paranã em Goiás, Brasil. Master's thesis, Instituto de Biociências, Universidade Estadual Paulista, Botucatu.

Cheliak, W.M. and Pitel, J.A. (1984). Techniques for Starch Gel Electrophoresis of Enzymes from Forest Tree Species. Patawawa National Forestry Institute, Canadian Forestry Service Information Report PI-X-42, p. 49.

Conkle, M.T., Hodgskiss, P.D., Nunnally, L.B. and Hunter, S.C. (1982). Starch Gel Electrophoresis of Conifer Seeds: A Laboratory Manual. Pacific Southwest Forest and Range Experimental Station, California, p. 17.

Durham, R.E., Liou, P.C., Gmitter Jr., F.G. and Moore, G.A. (1992). Linkage of restriction fragment length polymorphisms and isozymes in Citrus. Theor. Appl. Genet. 84: 39-48.

Esen, A. and Scora, R.W. (1977). Amylase polymorphism in Citrus and some related genera. Am. J. Bot. 64: 305-309.

Gogorcena, Y. and Ortiz, J.M. (1993). Use of multivariate analysis in the taxonomy of Citrus aurantium L. and relatives. Sci. Hortic. 53: 301-310.

Gogorcena, Y., Zubrzycki, H. and Ortiz, J.M. (1990). Identification of mandarin hybrids with the aid of isozymes from different organs. Sci. Hortic. 41: 285-291.

Handa, T., Ishizawa, Y. and Oogaki, C. (1986). Phylogenetic study of Fraction I protein in the genus Citrus and its close related genera. Jpn. J. Genet. 61: 15-24.

Herrero, R., Asins, M.J., Carbonell, E.A. and Navarro, L. (1996). Genetic diversity in the orange subfamily Aurantioideae. I. Intraspecies and intragenus genetic variability. Theor. Appl. Genet. 92: 599-609.

Hodgson, R.W. (1967). Horticultural varieties of citrus. In: The Citrus Industry (Reuther, W., Webber, H.J. and Batchelor, L.D., eds). Vol. I. Univer- sity of California Press, Berkeley, pp. 431-589.

Iglesias, L., Lima, H. and Simon, J.P. (1974). Isoenzyme identification of zygotic and nucellar seedlings in Citrus. Heredity 65: 81-84.

Jarrel, D.C., Roose, M.L., Traugh, S.N. and Kupper, R.S. (1992). A genetic map of Citrus based on the segregation of isozymes and RFLPs in an intergeneric cross. Theor. Appl. Genet. 84: 49-56.

Rohlf, F.J. (1992). NTSYS-pc: Numerical Taxonomy and Multivariate Analysis System Version 1.7. Exeter Publ., New York.

Roose, M.L. (1988). Isozymes and DNA restriction fragment length polymorphisms in Citrus breeding and systematics. In: Proceedings of the XVI International Citrus Congress, Tel Aviv, Israel. Philadelphia/Rehovot, Balaban, pp. 155-165.

Sawazaki, H.E., Ladaslav, S., Pio, R.M. and Muller, G.W. (1992). Identificação de espécies de Citros mediante polimorfismo enzimático. Bragantia 51: 121-128.

Scora, R.W. (1975). On the history and origin of Citrus. Bull. Torrey Bot. Club 102: 369-375.

Scora, R.W. (1988). Biochemistry, taxonomy and evolution of modern cultivated Citrus. In: Proceedings of the XVI International Citrus Congress, Tel Aviv, Israel. Philadelphia/Rehovot, Balaban, pp. 277-287.

Soltis, D.E. and Soltis, P.S. (1989). Isozymes in Plant Biology. Discorides Press, Portland.

Swingle, W.T. and Reece, P.C. (1967). The botany of Citrus and its wild relatives. In: The Citrus Industry (Reuther, W., Webber, H.J. and Batchelor, L.D., eds). Vol. I. University of California Press, Berkeley, pp. 190-422.

Swofford, D.C. and Selander, R.B. (1989). Biosys-1: A Computer Program for the Analysis of Allelic Variation in Population Genetics and Biochemical Systematics. Release 1.7, Natural History Survey, Champaign, IL, p. 43.

Tanaka, T. (1954). Species Problem in Citrus. Janpanese Society for the Promotion of Science, Tokyo.

Tanksley, S.D. and Orton, T.J. (Eds.) (1983). Isozymes in Plant Genetics and Breeding. Part A. Elsevier, New York.

Torres, A.M., Soost, R.K. and Diedenhofen, U. (1978). Leaf isozymes as genetic markers in Citrus. Am. J. Bot. 65: 869-881.

Torres, A.M., Soost, R.K. and Lastovicka, T.M. (1982). Citrus isozymes: Genetics and distinguishing nucellar from zygotic seedlings. Heredity 73: 335-339.

Torres, A.M., Mau-Lastovicka, T., Williams, T.E. and Soost, R.K. (1985). Segregation distortion and linkage of Citrus and Poncirus isozyme genes. Heredity 76: 289-294.

Vardi, A. (1988). Applications of recent taxonomical approaches and new techniques to citrus breading. In: Proceedings of the XVI International Citrus Congress, Tel Aviv, Israel. Philadelphia/Rehovot, Balaban, pp. 303-308.

(Received January 8, 1998) 